\title{
Effects of Wildlife on Cattle Diets in Laikipia Rangeland, Kenya
}

\author{
Wilfred O. Odadi, ${ }^{1}$ Truman P. Young, ${ }^{2}$ and J. B. Okeyo-Owuor ${ }^{3}$ \\ Authors are ${ }^{1} \mathrm{PhD}$ candidate, Natural Resource Management Dept, Egerton University, PO Box 536, Njoro, Kenya, \\ and Research Scientist, Mpala Research Centre, PO Box 555, Nanyuki, Kenya; ${ }^{2}$ Professor, Dept of Plant Sciences, \\ University of California, Davis, CA 95616, and Research Scientist, Mpala Research Centre, PO Box 555, Nanyuki, \\ Kenya; and ${ }^{3}$ Senior Lecturer, School of Environmental Studies, Biological Sciences Division, Moi University, \\ PO Box 3900, Eldoret, Kenya.
}

\begin{abstract}
The impacts of wild herbivores on cattle diet selection were investigated in an East African rangeland during August 2001 and February 2002. The study compared cattle diets in plots exclusively accessible to cattle (C) and those accessible to megaherbivores (elephants and giraffes), non-megaherbivore wild herbivores $>15 \mathrm{~kg}$ (zebras, hartebeests, Grant's gazelles, oryx, elands, and buffaloes) and cattle (MWC); or non-megaherbivore wild herbivores and cattle (WC). There were no treatment differences in selection of most grass species in either sampling period $(P>0.05)$. However, selection of forbs differed among treatments during February when conditions were relatively dry and percent of bites taken by cattle on this forage class increased $(P<0.005)$ from $1.8 \% \pm 0.3$ to $7.7 \% \pm 1.6$ (mean $\pm \mathrm{SE}$ ). During this period, cattle took a lower percent of bites on forbs in MWC $(4.3 \% \pm 1.7$; $P=0.01)$ and WC $(5.9 \% \pm 2.2 ; P=0.03)$ than in C $(12.9 \% \pm 0.9)$. These patterns were generally driven by Commelina spp., which comprised $65 \% \pm 9.4$ of total bites on forbs. Notably, these differences were associated with differences in cover of forbs, which was positively correlated with percent of bites on forbs $\left(r^{2}=0.86, P<0.01\right)$. Because forbs may be critical components of cattle diets in such rangelands during relatively dry periods, these dietary changes may indicate potential seasonal costs of wildlife to cattle production. Looking for ways to offset such costs may be worthwhile for livestock properties that accommodate wildlife.
\end{abstract}

\section{Resumen}

Los impactos de los herbívoros silvestres sobre selección de la dieta del ganado fueron investigados en un pastizal del este de África de Agosto del 2001 a Febrero del 2002. En el estudio se compararon las dietas del ganado en potreros accesibles exclusivamente al ganado (C) y en potreros accesibles a megaherbívoros (elefantes y jirafas), herbívoros silvestres mayores de $15 \mathrm{~kg}$ (zebras, ñus, gacelas, oryx, alce africano y búfalos) y ganado (MWC) y en potreros accesibles a no-mega herbívoros silvestres y ganado (WC). En ninguna de las épocas de muestro hubo diferencia entre tratamientos en la selección para la mayoría de especies de zacates $(P>0.05)$. Sin embargo, en Febrero, cuando las condiciones fueron relativamente secas, la selección de hierbas difirió entre tratamientos y el porcentaje de mordidas efectuadas por el ganado en esta clase de forraje aumentó $(P<0.005)$ de $1.8 \% \pm 0.3$ a $7.7 \% \pm 1.6$. Durante este periodo, el ganado registró porcentajes de mordidas de hierbas más bajos en los potreros MWC $(4.3 \% \pm 1.7 ; P=0.01)$ y WC $(5.9 \% \pm 2.2 ; P=0.03)$ que en los accesibles solo al ganado $(12.9 \% \pm 0.9)$. estos patrones generalmente estuvieron regidos por las plantas del género Commelina spp., las cuales comprendieron $65 \% \pm 9.4$ del total de las mordidas de hierbas. Estas diferencias estuvieron notablemente asociadas con diferencias en la cobertura de hierbas, la que fue positivamente correlacionada con el porcentaje de mordidas $\left(r^{2}=0.86\right.$, $P<0.01)$. Debido a que las hierbas pueden ser un componente crítico de la dieta del ganado en estos pastizales durante periodos relativamente secos, estos cambios en la dieta pueden indicar costos estaciónales potenciales de la fauna silvestre para la producción de ganado. La búsqueda de formas de compensar tales costos puede ser de valor para las propiedades productoras de ganado que alojan fauna silvestre.

Key Words: forbs, livestock, megaherbivores, nutrition, productivity, wild herbivores

\section{INTRODUCTION}

The exclosure plots were built and maintained with grants from the James Smithson Fund of the Smithsonian Institution (to A.S.), the National Geographic Society (4691-91), the National Science Foundation (BSR-97-07477 and BSR-03-16402), and the African Elephant Program of the US Fish and Wildlife Service (98210-0-G563) (to T.P.Y). The latter 2 grants also supported the research reported here. This research was carried out under the auspices of the Mpala Research Centre and The Office of the President of the Republic of Kenya (Ref MOEST/13/001/8C 20).

At the time of research, the principal author was an MSc student, School of Environmental Studies, Biological Sciences Division, Moi University, P0 Box 3900, Eldoret, Kenya, and Junior Research Scientist, Mpala Research Centre, P0 Box 555, Nanyuki, Kenya.

Correspondence: Wilfred 0. Odadi, Mpala Research Centre, P0 Box 555, Nanyuki, Kenya. Email: woodadi@yahoo.com

Manuscript received 27 February 2005; manuscript accepted 3 November 2006.
East African rangelands are known for their abundant and diverse assemblages of wildlife (Boutton et al. 1988; Kinyamario and Macharia 1992; Voeten and Prins 1999). Notably, large proportions of wildlife are found outside protected areas on privately owned unfenced livestock ranches and communal grazing areas (Western 1989). Livestock owners have become concerned about the negative impacts on cattle production often associated with wildlife (Prins 1992; Prins and Grootenhuis 2000). Inability of landowners to derive direct benefits from wildlife has exacerbated the problem and led to extirpation of (larger) wildlife from some private and communal properties in nonprotected areas (Heath 2000). As a result, there is growing 
recognition that the future of wildlife conservation in rangelands outside protected areas will depend partly on better assessments of the costs to livestock producers and the need for potentially offsetting such costs.

Direct competition for forage resources between wild herbivores and livestock can lead to changes in foraging behaviors and diet selection, which alter performance and population dynamics (Hepworth et al. 1991). Although several studies have shown that livestock can have negative effects on wild herbivores (Prins 2000; Young et al. 2005), there still is little scientific information on the effects of wild herbivores on livestock (Hobbs et al. 1996a, 1996b), in African rangelands in particular (Prins 2000). The objective of this study was to investigate the impact of large wild herbivores on cattle diet selection in a semiarid East African rangeland.

\section{MATERIALS AND METHODS}

\section{Study Area}

The study was conducted at Mpala Research Centre (lat $0^{\circ} 17^{\prime} \mathrm{N}$, long $37^{\circ} 52^{\prime} \mathrm{E}, 1800 \mathrm{~m}$ above sea level) situated on a rangeland in the central part of Laikipia District, Kenya. The climate is semiarid with an average annual rainfall of $550 \mathrm{~mm}$. Generally, long rains occur in March-May, the short rains in October and November, and continental rains in July and August (Young et al. 1998). This study was conducted during August 2001 and February 2002. August was wet, with rainfall totalling about $61 \mathrm{~mm}$ in this period and $207 \mathrm{~mm}$ in the preceding 3 months. Although February itself was relatively dry, with no rainfall being recorded in this month or in January, it was preceded by heavy rains, amounting to $297 \mathrm{~mm}$ in October and November.

The main soil type is black cotton soil. The main vegetation type in the study site is grassland or bushed grassland with varying densities of Acacia drepanolobium Sjøstedt (whistling thorn). The herb-layer vegetation is dominated by perennial grasses, namely, Pennisetum stramineum Peter (Masai grass), P. mezianum Leeke (bamboo grass), Brachiaria lachnantha (Hochst.) Stapf, Themeda triandria Forsk. (red oat grass), and Lintonia nutans Stapf (Young et al. 1998). Annual grasses found in the study site include Dinebra retroflexa (Vahl) Panzer, Tragus berteronianus Schult. (carrot seed grass), Panicum atrosanguineum Hochst. ex A. Rich., and Brachiaria semindulata Hochst. ex A. Rich.; forbs include Solanum spp. L., Aspilia pleuriseta Schweinf., Commelina spp. L., Helichrysum glumaceum DC, Dischoriste radicans Nees and Rhinacanthus ndorensis Schweinf.

Over 75 mammal species are found within Mpala Research Centre and its environs (Young et al. 1998). The most common large herbivores in the study area include Boran cattle (Bos indicus), zebras (Equus burchelli and E. grevyi), buffaloes (Syncerus caffer), hartebeests (Alcelaphus buselaphus), elands (Tragelaphus oryx), oryx (Oryx gazella beisa), Grant's gazelles (Gazella granti), elephants (Loxodonta africana) and giraffes (Giraffa camelopardalis).

\section{Experimental Plots}

We used a set of 4-ha experimental plots established in 1995 by the Kenya Long-Term Exclosure Experiment (KLEE) consisting of a series of semipermeable barriers that differentially exclude or allow cattle, megaherbivores (elephants and giraffes) and non-megaherbivore large wild herbivores $>15 \mathrm{~kg}$ (zebras, hartebeests, Grant's gazelles, oryx, elands, and buffaloes). We used plots with 3 herbivory treatments, namely, only cattle allowed $(\mathrm{C})$; megaherbivores, non-megaherbivore large wild herbivores, and cattle allowed (MWC); and non-megaherbivore large wild herbivores and cattle allowed (WC), where plots were replicated across 3 blocks (central, north, and south) in a randomized block design, resulting in a total of 9 plots. The experimental barriers have since been demonstrated to be effective in excluding the targeted groups of large herbivores (Young et al. 1998, 2005). For details of the site and experimental setup, see Young et al. (1998).

\section{Cattle Runs and Wildlife Densities}

KLEE conducted timed 2-hour cattle runs consisting of 120 Bos indicus cows in each of the treatment plots used in this study 4-8 times per year, designed to reflect the ranch stocking rate of $0.1-0.2$ cattle $\cdot \mathrm{ha}^{-1} \cdot \mathrm{y}^{-1}$ (see Young et al. 2005). Prior to the first vegetation sampling period in August 2001, 3 cattle runs were conducted in January, April/May and July of that year. Three more runs were conducted in September, November, and January prior to sampling in February 2002.

Although we did not determine the density of large wild herbivores in the specific study site during our study, mean densities of megaherbivores and non-megaherbivore large wild herbivores in Laikipia District are $0.004 \pm 0.002$ and $0.05 \pm 0.01$ animals $\cdot \mathrm{ha}^{-1}$, respectively based on aerial sample surveys conducted between 1985 and 2005 (N. J. Georgiadis, unpublished). These densities are characterized by wide spatial and temporal variations but are generally higher in properties that are more accommodative to wildlife such as Mpala Ranch, where our study site was located (N. J. Georgiadis, unpublished).

\section{Vegetation Surveys}

We obtained percent canopy cover data for the herb-layer vegetation in the study plots from KLEE vegetation surveys conducted in 1995 (baseline) and sampled vegetation cover 2-3 weeks before each of the 2 sampling periods. Consistent with past surveys, the vegetation sampling was conducted in the central hectare of each plot along ten 100-m line transects with the use of a 10-pin frame at 100 evenly spaced sampling points ( 1000 pins per plot). At each sampling point, pin hits were recorded for plant species in contact with each pin (maximum 10 pin hits per species). For each study plot, cover was calculated as total pin hits on a species divided by total number of pins (1 000). Although we did not directly measure the standing biomass of herb-layer vegetation species in this study, calibrations developed for the study site reveal strong positive correlations between cover and biomass of most plant species $(r=0.58-0.91$, all $P<0.01$; I. Kimathi and T. P. Young, unpublished data, 2006). Thus, cover estimates for most herb-layer vegetation species and classes were representative of their respective availabilities.

\section{Estimation of Cattle Diet Selection}

Cattle diet selection was determined in August 2001 and February 2002. At the beginning of each sampling period, 10 


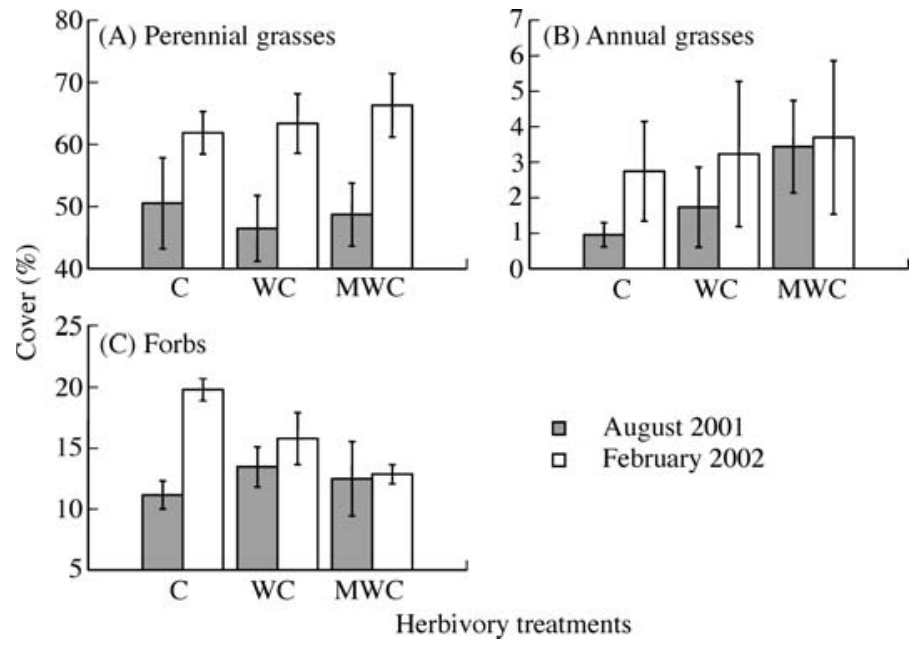

Figure 1. A, Percent cover of perennial grasses across different herbivory treatments. B, Percent cover of annual grasses across different herbivory treatments. C, Percent cover of forbs across different herbivory treatments during the 2 sampling periods. Bars represent 1 standard error $(n=3)$. $C=$ plots exclusively accessible to cattle. $\mathrm{MWC}=$ plots accessible to megaherbivores (elephants and giraffes), non-megaherbivore wild herbivores $(>15 \mathrm{~kg}$ ) and cattle. $\mathrm{WC}=$ plots accessible to non-megaherbivore wild herbivores and cattle.

Boran heifers aged about 3 years were randomly selected from Mpala Ranch. Before data collection, the selected heifers were herded together for 7 days to habituate them to one another. During this period, trial observations were made to prepare the animals for close-range observation. For each experimental block, 3-5 focal heifers were randomly picked with replacement from the 10 heifers for observation across treatment plots within the block. Treatment plots were sampled on different days.

On each sampling day, all 10 heifers were moved into a desired plot at 0800-0900 hours and removed 2 hours later. As they walked to each experimental plot each morning, they moved and fed through similar background vegetation. The animals were allowed a settling period of 10 minutes to move first to a random location within the plot prior to commencement of sampling. The focal heifers were then observed in 2 rounds, where each individual was observed for 10 minutes in each round for the number of bites on different plant species. Whenever the focal animal bit more than one species at a time, which was rare, a single bite was recorded for each species. In situations where the plant species consumed was not readily identifiable to the observer, it was collected and coded for identification afterwards. The time interval between focal observations on cattle in each plot was about 2 minutes. All observations were made at a distance of less than $4 \mathrm{~m}$ from the focal animal.

The use of bite counts to infer consumption can be problematic because of difficulties in quantifying how much of a plant was consumed (Holechek et al. 1982; Mayes and Dove 2000). We minimized biases associated with this limitation by using the proportion of bites rather than absolute bite count values in our analyses to infer relative use of different forage plants. Selection ratios for each focal observation period were calculated by dividing percent of bites on a given plant species by its relative cover in the entire study plot. This approach may have biased selection ratio values in each observation period because it did not take into account vegetation along respective grazing paths of the focal animals. However, mean selection ratio values for individual focal animals and plots were less likely to be affected by this limitation because they were averaged over multiple focal samples per plot. Furthermore, this limitation was likely to be minimal because vegetation in the study site is relatively uniform (Young et al. 1998).

\section{Statistical Data Analysis}

Experimental units were treatment plots replicated across experimental blocks $(n=3)$, with test animals being used as plot subsamples. For each plot, data for each focal animal were averaged across the two 10-minute observation periods to give individual animal means, which were then averaged across animals to give plot means. This minimized autocorrelation within animals. The resulting data sets for each sampling period were analyzed with the use of Systat (SPSS 1998), where the general linear model (GLM) of analysis of variance (ANOVA) with block effects was used to test for differences in percent of bites taken by cattle on different forage plants among the 3 treatments (C, WC, and MWC). Similar analyses were used to test for vegetation cover differences among treatments. Tukey's HSD multiple comparisons test was performed in post hoc tests of means. Because selection ratio estimates were in most cases heavily skewed, we used the nonparametric Mann-Whitney test to test for treatment differences in selection of forage plants.

\section{RESULTS}

\section{Vegetation Cover Within Treatments}

The 1995 baseline vegetation data demonstrate considerable homogeneity among plots within treatment classes at the time of establishment of the study plots. Total herb-layer vegetation cover was within $4 \%$ of the overall mean $(60.7 \% \pm 1.2 \mathrm{SE})$ in each of the 9 plots used in this analysis, and there were no significant block $(P=0.61)$ or treatment $(P=0.28)$ effects. In addition, there were no significant pretreatment differences $(P>0.2)$ for herb-layer vegetation species or overall in cover of perennial grasses (mean cover $=53.7 \% \pm 1.4$ ), annual grasses $(0.0 \% \pm 0.0)$, or forbs $(7 \% \pm 0.9)$. Even Commelina spp., which occurred at relatively low abundance at this time (mean cover $<1 \%)$ did not differ among plots $(P>0.25)$.

Grass cover did not differ among treatments in either sampling period $(P>0.1$, Figs. $1 \mathrm{~A}$ and $1 \mathrm{~B})$. Forb cover did not differ among treatments in August $(P=0.4$, Fig. $1 \mathrm{C})$. In February, however, the total cover of forbs was significantly less in MWC $(P=0.04)$ but not in WC $(P=0.23)$ than in C (Fig. 1C). Excluding Aspilia spp. and Solanum spp., which did not comprise cattle bites but accounted for a high proportion $(8 \%-$ $27 \%$ ) of total cover of forbs, these reductions were even stronger $(13.8 \% \pm 1.16$ in $\mathrm{C}$ compared to $6.9 \% \pm 0.76$ in MWC, $P<0.01$, and $10.1 \% \pm 1.19, P=0.04$ in WC). Commelina spp. followed a similar pattern with higher cover in $\mathrm{C}$ $(4.5 \% \pm 0.6)$ than in MWC $(1.6 \% \pm 0.5, P=0.04)$ but not in WC $(2.9 \% \pm 0.4, P=0.22)$. 


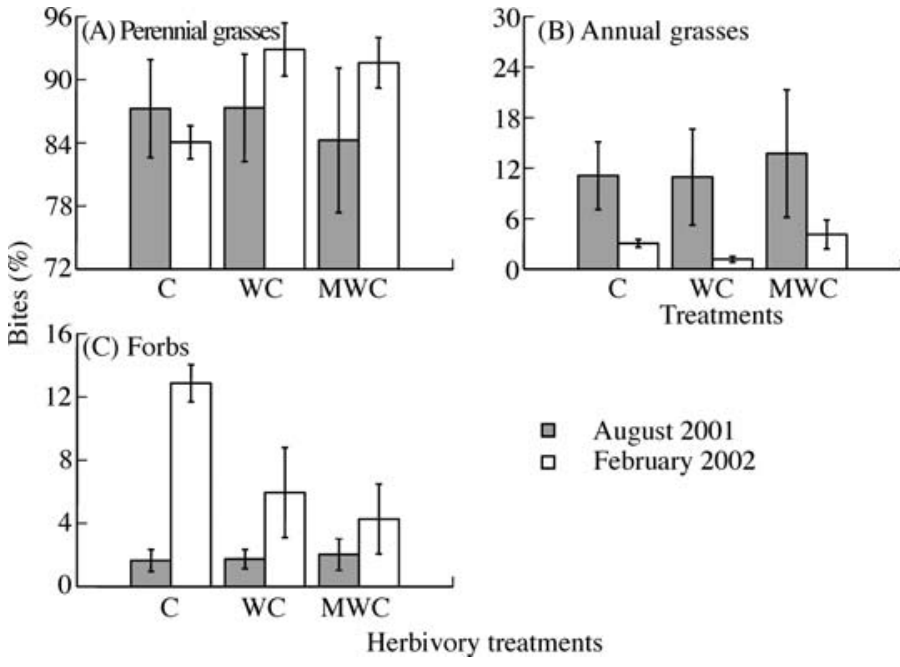

Figure 2. A, Percent of bites taken by cattle on perennial grasses across treatments. B, Percent of bites taken by cattle on annual grasses across treatments. C, Percent of bites taken by cattle on forbs across treatments at different sampling periods. Bars represent 1 standard error $(n=3)$. $\mathrm{C}=$ plots exclusively accessible to cattle. $\mathrm{MWC}=$ plots accessible to megaherbivores (elephants and giraffes), non-megaherbivore wild herbivores $(>15 \mathrm{~kg})$ and cattle. $W C=$ plots accessible to nonmegaherbivore wild herbivores and cattle.

\section{Cattle Diet Selection}

We counted a total of 34312 bites in 90, 10-minute focal animal observations in August and 14195 bites in 61 focal observations in February. Cattle were observed to eat grasses and forbs but not woody plants in either sampling period. Overall, perennial grasses accounted for the highest percentage of cattle bites across study plots in either sampling period (Figs. 2A-2C). T. triandra accounted for the highest proportion of total bites both in August $(32 \%-41 \%)$ and in February $(46 \%-52 \%)$. B. lachnantha constituted the second largest proportion of bites $(21 \%-40 \%$ in August, $10 \%-14 \%$ in February). Other perennial grasses comprising cattle bites during the 2 sampling periods were P. stramineum (11\%-16\% of total bites), L. nutans $(1 \%-16 \%)$, and $P$. mezianum $(3 \%-5 \%)$.

There was no correlation between proportion of bites on perennial grasses and total grass cover in either sampling period $\left(r^{2}<0.1, P>0.3\right)$. The overall proportion of bites and selection ratio of these grasses also did not differ among treatments in August $(P=0.24$, Fig. 2A). Likewise, selection and percent of bites on individual perennial grass species did not differ among treatments $(P>0.2)$, except for B. lachnantha, which was higher in $\mathrm{C}(39.4 \% \pm 2.8)$ than in WC $(20.6 \% \pm 2.2$, $P=0.01)$ and MWC $(27.8 \% \pm 0.7, P=0.03)$. However, percent of bites on this grass was not correlated with its cover $\left(r^{2}=0.1, P=0.55\right)$, which was not different among treatments $(P>0.3)$. In February, the overall percent of bites on perennial grasses was negatively correlated with total cover of forbs $\left(r^{2}=0.62, P=0.01\right)$, and was lower in treatments WC $(P=0.01)$ and MWC $(P=0.02)$, which had less forb cover (Figs. 1C and 2A). However, the proportions of bites and selection ratios of individual perennial grass species did not differ among treatments during this sampling period $(P>0.1)$.

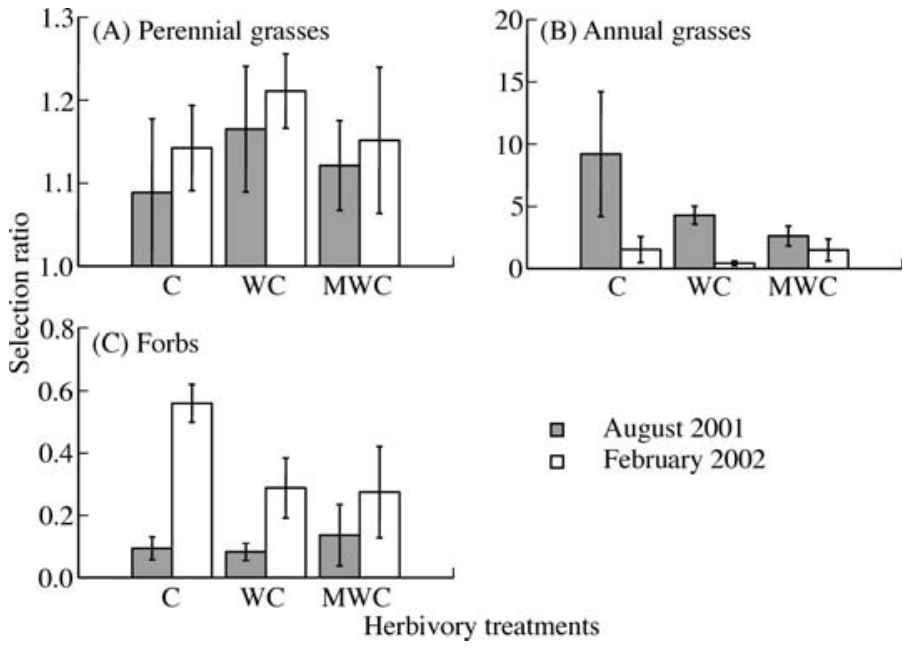

Figure 3. A, Selection ratio of perennial grasses across different herbivory treatments. B, Selection ratio of annual grasses across different herbivory treatments. C, Selection ratio of forbs across different herbivory treatments at different sampling periods. Bars represent 1 standard error $(n=3)$. $C=$ plots exclusively accessible to cattle. $M W C=$ plots accessible to megaherbivores (elephants and giraffes), non-megaherbivore wild herbivores $(>15 \mathrm{~kg}$ ) and cattle. WC = plots accessible to non-megaherbivore wild herbivores and cattle. Selection ratios were calculated by dividing percent bites on each forage class by its relative cover in the study plots.

The correlation between percent of bites on annual grasses and their cover was not significant in either sampling period $\left(r^{2}<0.40, P>0.07\right)$. The overall selection ratio and percent of bites on annual grasses did not differ significantly among treatments (all $P>0.1$, Figs. $2 \mathrm{~B}$ and 3B). The pattern of selection and consumption of annual grasses across treatment plots was driven by $D$. retroflexa, which accounted for the highest proportion $(50 \%-65 \%)$ of total bites on annual grasses.

In August, forb cover and the proportion of bites taken by cattle on forbs were not correlated $\left(r^{2}=0.23, P=0.2\right)$, and there were no differences in the overall proportion of bites and selection ratio of forbs among plots (Figs. 2C and $3 \mathrm{C}$ ). In February, however, forbs constituted a higher proportion of the bites taken by cattle, and their cover was positively correlated with their proportion of bites $\left(r^{2}=0.86, P<0.01\right.$; Fig. 4$)$. As a result, percent of bites on forbs was lower in WC $(P=0.03)$ and MWC $(P=0.01)$ than in $\mathrm{C}$ (Fig. 2C). Similarly, selection ratio of forbs was lower in WC $(P=0.05)$, but not in $\mathrm{MWC}$ $(P=0.1)$ than in $\mathrm{C}$ (Figs. $2 \mathrm{C}$ and $3 \mathrm{C}$ ). These patterns were generally driven by Commelina spp., which comprised the highest proportion $(65 \% \pm 9.4)$ of total bites on forbs. In August, the proportion of bites taken by cattle on this forb was not correlated with its cover $\left(r^{2}=0.02, P=0.72\right)$, and did not differ significantly $(P=0.57)$ among treatments $(1 \% \pm 0.2$ in C, $1.3 \% \pm 0.4$ in WC, $1.7 \% \pm 0.5$ in MWC). In February, however, percent of bites on Commelina spp. was positively correlated with its cover $\left(r^{2}=0.61, P=0.01\right)$, and was higher in $\mathrm{C}(9.5 \% \pm 1.1)$ than in MWC $(1.5 \% \pm 0.8$, $P=0.01)$ but not in WC $(5.1 \% \pm 0.8, P=0.06)$. Selection ratio of Commelina averaged higher among cattle in $\mathrm{C}$ $(1.8 \pm 0.25)$ than in MWC $(0.7 \pm 0.3, P=0.05)$, but not in WC $(1.5 \pm 0.62, P=0.51)$. 


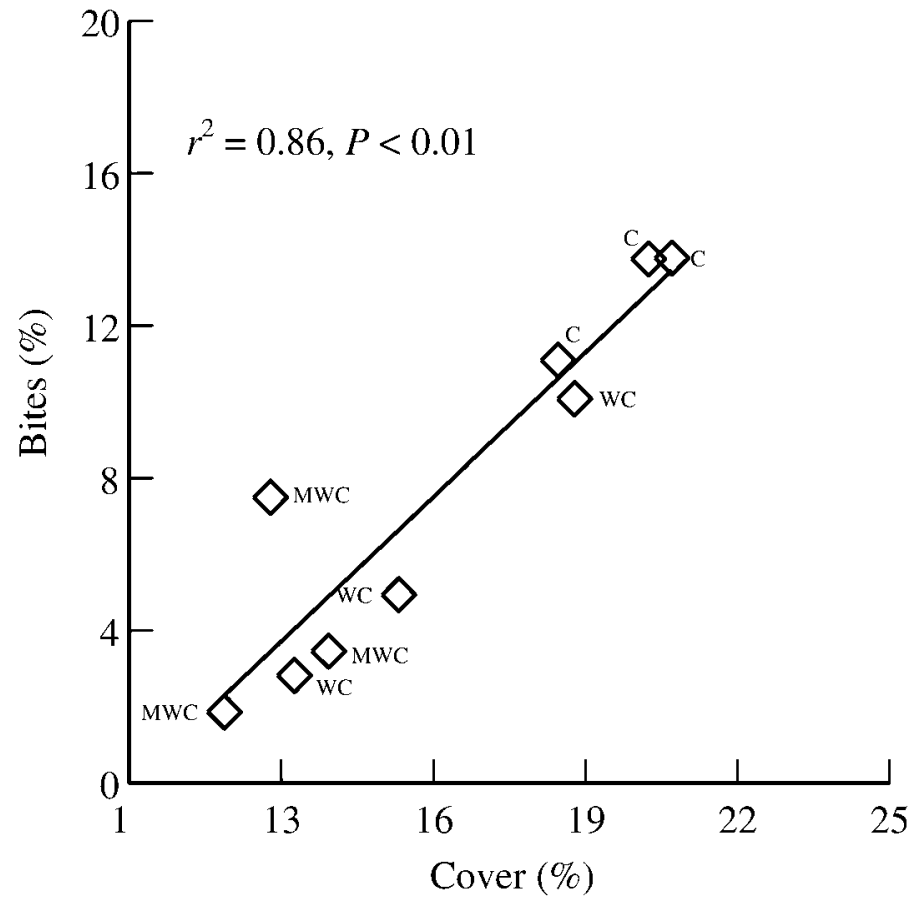

Figure 4. Relationship between forb cover and proportion of bites taken by cattle on forbs across the 9 study plots during the February 2002 sampling period. $\mathrm{C}=$ plots exclusively accessible to cattle. $\mathrm{MWC}=$ plots accessible to megaherbivores (elephants and giraffes) non-megaherbivore wild herbivores $(>15 \mathrm{~kg}) . W C=$ plots accessible to non-megaherbivore wild herbivores and cattle.

\section{DISCUSSION}

Differences in diets of cattle among treatment plots were largely driven by differences in availabilities of plant species or guilds consumed by cattle. Therefore, the use of most grasses, including the highly selected annual species, did not differ among treatments because grass cover was similar among plots (Figs. 1 and 2). The exception was B. lachnantha in August, which was not related to its cover. Because $B$. lachnantha appears to be an important dietary component of cattle in this ecosystem, based on its high proportion of total bites $(10 \%-40 \%)$, changes in its intake may alter cattle foraging patterns and overall intake (Odadi 2003). Because B. lachnantha cover was similar across plots, it is not clear from this study what factors drove the observed differences in its use by cattle among treatment plots. Further, without this clarification it is unclear how and to what extent differential use of this grass by cattle is related to previous use by wildlife.

The differences in consumption of forbs among plots were largely driven by forb cover (Figs. 1C, 2C, and 4). These differences were associated with wildlife impacts, because pretreatment forb cover was similar across study plots (Young et al. 1998). Similar reductions in forb cover have been reported for these experimental plots in 2000 and early 2001, when conditions were generally dry (Odadi 2003; Young et al. 2005). However, these differences among treatments in availability of forbs disappeared in August 2001, when conditions were relatively wet (Figs. 1C, 2C, and 3C), indicating that the influence of previous grazing by wildlife may be short-term within season and dependent on weather conditions. The observed higher selection ratio of forbs in plots from which wildlife were excluded was not related to a reduction in availability of forbs, but an increase in forb intake by cattle (Figs. 1C, 2C, 3C, and 4). Because forbs as a whole were not strongly selected for (Fig. 3C), their importance to cattle in this ecosystem appears to be largely driven by Commelina spp., based on its observed positive selection (selection ratio $=0.7-1.8$ ) .

Despite the relatively high grass cover in February (Fig. 1A) associated with high precipitation in the last quarter of the preceding year, grass quality was possibly lower, because of maturational accumulation (Wilmshurst et al. 1999). Although we did not determine forage quality in this study, digestibility and crude protein levels of most grasses in such semiarid systems often fall below minimum maintenance requirements of cattle $7 \%$ crude protein and $50 \%$ dry matter digestibility) during such dry periods (Dougall et al. 1964; Field 1972; Karue 1974; Boutton et al. 1988). In contrast, forbs maintain relatively high nutritive levels, which are often above these minimum requirements (Boutton et al. 1988). Studies conducted at Nairobi National Park, which is generally similar to our study site in terms of climate, soils and vegetation, have reported lower levels of crude protein $(<5 \%)$ and dry matter digestibility $(<41 \%)$ in mature grasses than in forbs $(>10 \%$, $>50 \%$, respectively) (Boutton et al. 1988; Kinyamario and Macharia 1992). Even T. triandra, which constituted the bulk $(36 \%-50 \%)$ of cattle bites in the present study, has been reported to contain relatively low levels $(2 \%-4 \%)$ of crude protein when mature, in similar systems (Dougall and Glover 1964; Kinyamario and Macharia 1992). In contrast, Commelina spp., the forb most used by cattle in the present study, has been reported to contain relatively high levels $(8 \%-20 \%)$ of crude protein (Dougall et al. 1964).

Based on the nutritional differences between forbs and grasses, differential selection and use of forbs may have important nutritional implications on cattle. Forbs are generally known to have a much more rapid rate of digestion and higher passage rate than grasses (Kothman 1980; McCollum and Galyean 1985). During periods of relatively low grass quality, utilization of forbs may be important to bulk-feeding ruminants like cattle in enhancing their digesta fermentation and passage rates, leading to extended feeding time and higher overall intake (Zimmermann 1980; Skinner et al. 1983; McCollum and Galyean 1985; Beekman and Prins 1989). Because cattle diet quality and digesta kinetics were not analyzed in this study, the actual nutritional changes associated with the observed $7 \%-$ $9 \%$ difference in use of forbs by cattle among plots (Fig. 2C) are unknown. However, there is evidence that this magnitude of change in dietary contribution of forbs may be sufficient to alter cattle nutrition. With a similar magnitude of increase in forb content of cattle diets, Judkins et al. (1987) reported substantial increases in dietary crude protein $(10.4 \%-12.6 \%)$, dry matter digestibility $(42 \%-48 \%)$ and particulate passage rate $(3.4 \% / \mathrm{h}-$ $3.9 \% / \mathrm{h}$ ) on a blue grama rangeland in New Mexico. Similarly, in a south African savanna, an increase in cattle diet forb content from $4 \%$ to $12 \%$ was enough to increase dietary crude protein from $5.9 \%$ to $11.1 \%$, and organic matter digestibility from $55 \%$ to $63 \%$ (Zimmermann 1980; Skinner et al. 1983). 
Because plots accessible to wildlife were grazed by several species of wildlife, we were unable to directly associate the observed differential selection and use of forbs by cattle with specific wildlife species (see Young et al. 1998). However, we suspect that these effects were mainly associated with the most frequent forb-consuming wild herbivores in the wildlife accessible plots during the study (see Young et al. 2005). In particular, megaherbivore impacts were likely due to elephants, which are known to feed extensively on forbs and other herblayer plants (Kabigumila 1993; Codron et al. 2005). Specifically, elephants appear to affect availability of Commelina spp., as has been reported elsewhere (Young et al. 2005). In contrast, the other megaherbivore species, giraffes, rarely feed on the vegetation below $50 \mathrm{~cm}$ (Young and Isbell 1991). Elands were the most likely non-megaherbivores to reduce forb abundance, based on their documented high preference for forbs (Field 1975; Codron et al. 2005) and high frequency in the study plots accessible to wildlife (Young et al. 2005). Although zebras and hartebeests were frequent in the study plots (Young et al. 2005), they were not likely to drive differences in forb availability because they feed almost entirely on grass (Voeten and Prins 1999; Ego et al. 2003).

\section{MANAGEMENT IMPLICATIONS}

Our study revealed that wild herbivores may affect cattle diets through reductions in forb availability and consumption by cattle during dry periods when grass quality is likely to be relatively low. This appears to be one of the first studies to provide experimental evidence that previous wildlife grazing may potentially affect cattle. Grazing by wildlife in this ecosystem has also been reported to alter cattle foraging patterns (step and bite rates), potentially leading to lower forage intake (Odadi 2003). Likewise, in North America, grazing by the Rocky Mountain elk (Cervus elaphus canadensis) has been reported to affect cattle forage intake through reductions in forage availability (Hobbs et al. 1996a, 1996b). The dietary changes reported in the present study may potentially alter cattle nutrition and forage intake (McCollum and Galyean 1985; Beekman and Prins 1989), indicating potential seasonal costs of wildlife to cattle production in such rangelands. Because such costs can potentially reduce profitability of cattle production, looking for ways to offset them would be worthwhile for livestock properties that host wildlife. However, the efficacy of such mitigation cannot be discerned without further assessment of the actual implications of such dietary changes in terms of cattle productivity. We have recently initiated studies designed to examine the specific implications of the dietary changes reported here on cattle productivity, with the use of both KLEE exclosures, and an additional set of experiments similar in design to Hobbs et al. (1996a, 1996b).

\section{ACKNOWLEDGMENTS}

We thank Nick Georgiadis, Ken Wreford Smith, and especially the late George Small for hosting us, and for providing the experimental site and animals; and Charles Warui and Frederick Erei for field assistance. Several reviewers and the associate editor provided useful comments and edits of the manuscript.

\section{LITERATURE CITED}

Beekman, J. H., And H. H. T. Prins. 1989. Feeding strategies of sedentary large herbivores in East Africa, with emphasis on the African buffalo, Syncerus caffer. African Journal of Ecology 27:129-147.

Boutton, T. W., L. L. Tieszen, and S. K. Imbamba. 1988. Seasonal changes in the nutrient content of East African grassland vegetation. African Journal of Ecology 26:103-115.

Codron, D., J. Codron, J. A. Lee-Thorp, M. Sponheimer, and D. de Ruiter. 2005. Animal diets in the Waterberg based on stable isotopic composition of faeces. South African Journal of Wildlife Research 35:43-52.

Dougall, H. W., V. M. Drysdale, and P. E. Glover. 1964. The chemical composition of Kenya browse and pasture herbage. East African Wildlife Journal 2:86-121.

Dougall, H. W., and P. E. Glover. 1964. On the chemical composition of Themeda triandra and Cynodon dactylon. East African Wildlife Journal 2:67-70.

Ego, W. K., D. M. Mbuvi, And P. F. K. Kibet. 2003. Dietary composition of wildebeest (Connochaetes taurinus) kongoni (Acephalus buselaphus) and cattle (Bos indicus), grazing on a common ranch in south-central Kenya. African Journal of Ecology 41:83-92.

FieLD, C. R. 1972. The food habits of wild ungulates in Uganda by analyses of stomach contents. East African Wildlife Journal 10:17-42.

FIELD, C. R. 1975. Climate and the food habits of ungulates on Galana Ranch. East African Wildlife Journal 13:203-220.

Heath, B. 2000. Ranching: an economic yardstick. In: H. H. T. Prins, J. G. Grootenhuis, and T. T. Dolan [EDS.]. Wildlife conservation by sustainable use. Boston, MA: Kluwer Academic. p 21-33.

Hepworth, K. W., P. S. Test, R. H. Hart, J. W. Waggoner, JR., and M. A. Smith. 1991. Grazing systems, stocking rates, and cattle behavior in Southeastern Wyoming. Journal of Range Management 44:258-261.

HobBs, N. T., D. L. BakeR, G. D. BeAR, and D. C. Bowden. 1996a. Ungulate grazing in sagebrush grassland: mechanisms of resource competition. Ecological Applications 6:200-217.

HobBs, N. T., D. L. Baker, G. D. Bear, and D. C. Bowden. 1996b. Ungulate grazing in sagebrush grassland: effects of resource competition on secondary production. Ecological Applications 6:218-227.

Holechek, J. L., M. Vavra, and R. D. Pieper. 1982. Botanical composition determination of herbivore diets: a review. Journal of Range Management 35:309-315.

Judkins, M. B., J. D. Wallace, M. L. Galyean, L. J. Krysl, and E. E. Parker. 1987. Passge rates, rumen fermentation, and weight change in protein supplemented grazing cattle. Journal of Range Management 40:100-105.

KabigumiLA, J. 1993. Feeding habits of elephants in Ngorongoro Crater, Tanzania. African Journal of Ecology 31:156-164.

Karue, C. N. 1974. The nutritive value of herbages in semi-arid lands of East Africa. 1. Chemical composition. East African Agricultural and Forestry Journal 40:89-95.

Kinyamario, J. I., AND J. N. M. Macharia. 1992. Above-ground standing crop, protein content and dry matter digestibility of a tropical grassland range in the Nairobi National Park, Kenya. African Journal of Ecology 30:33-41.

Kотнмan, M. M. 1980. Nutrition of livestock grazing on range and pasture lands In: D. C. Church [ED.]. Digestive physiology and nutrition of ruminants. 2nd ed. Corvallis, OR: 0 and B Books. p 56-90.

Mayes, R. W., AND H. Dove. 2000. Measurement of dietary intake in free-ranging mammalian herbivores. Nutrition Research Reviews 13:107-138.

McCollum, F. T., and M. L. Galyean. 1985. Cattle grazing blue grama rangeland II. Seasona. Forage intake and digesta kinetics. Journal of Range Management 36:543-546.

ODADI, W. 0. 2003. Effects of large mammalian herbivores on cattle foraging behaviour in an acacia savanna, Laikipia, Kenya (thesis). Eldoret, Kenya: Moi University. $105 \mathrm{p}$. 
Prins, H. H. T. 1992. The pastoral road to extinction-competition between wildlife and traditional pastoralism in East Africa. Environmental Conservation 19:117-123.

Prins, H. H. T. 2000. Competition between wildlife and livestock in Africa. In: H. H. T. Prins, J. G. Grootenhuis, and T. T. Dolan [EDS.]. Wildlife conservation by sustainable use. Boston, MA: Kluwer Academic. p 51-80.

Prins, H. H. T., and J. G. Grootenhuis. 2000. Introduction: the value of priceless wildlife. In: H. H. T. Prins, J. G. Grootenhuis, and T. T. Dolan [EDs.]. Wildlife conservation by sustainable use. Boston, MA: Kluwer Academic. p 1-12.

Skinner, J. D., R. H. Monro, and I. Zimmermann. 1983. Comparative food intake and growth of cattle and impala on mixed tree savanna. South African Journal of Wildlife Research 14:1-9.

SPSS. 1998. Systat 9. Chicago, IL: SPSS.

Voeten, M. M., And H. H. T. Prins. 1999. Resource partitioning between sympatric wild and domestic herbivores in the Tarangire region of Tanzania. Oecologia 120:287-294.
WeSteRn, D. 1989. Conservation without parks: wildlife in the rural landscape. In: D. Western and M. C. Pearl [EDS.]. Conservation for the twentyfirst century. Oxford, United Kingdom: Oxford University Press. p 158165.

Wilmshurst, J. F., J. M. Fryxell, and P. E. Colucci. 1999. What constrains daily intake in Thomson's gazelles? Ecology 80:2338-2347.

Young, T. P., And L. A. Isbell. 1991. Sex differences in giraffe feeding ecology: energetic and social constraints. Ethology 87:79-89.

Young, T. P., B. D. OKello, D. Kinyua, and T. M. Palmer. 1998. KLEE a long-term multi-species herbivore exclusion experiment in Laikipia Kenya. African Journal of Range and Forage Science 14:92-104.

Young, T. P., T. M. Palmer, and M. E. Gadd. 2005. Competition and compensation among cattle, zebras, and elephants in a semi-arid savanna in Laikipia, Kenya. Biological Conservation 122:351-359.

Zimmermann, I. 1980. Factors influencing the feed intake and live-weight change of beef cattle on a mixed tree savanna in the Transvaal. Journal of Range Management 33:132-136. 